\title{
Police Authority in Issuance of Music Performance Permits as Efforts to Control Security and Order
}

\section{Dian Rahayu Windyastuti ${ }^{*}$ and Umar Ma'ruf ${ }^{* *}$}

*) Student of Master of Law, Faculty of Law, Universitas Islam Sultan Agung (UNISSULA) and Police in Intelligence Unit of Pati, E-mail: dianrahayu.wnd@gmail.com

**) Faculty of Law, Universitas Islam Sultan Agung (UNISSULA) Semarang

\section{Abstract.}

The purpose of this study was to determine and analyze the regulatory procedures for the issuance of music stage permits, the authority of the National Police in issuing permits for music performances as an effort to control security and order and the inhibiting factors for the authority of the Police in issuing permits for music performances as an effort to control security and order. This study uses an empirical juridical approach. The conclusion of this study is about the Procedure for Issuance of a Music Performance Permit, namely; The permit applicant brings the requirements (a copy of the KTP and Recommendation for music performances, then the officer provides a Community Service Accountability Statement, Environmental Permit Statement, Location Permit Statement, after completing a Music Performance Permit issued by the Chief of Police, which is then submitted to the permit applicant. The authority of the National Police in issuing permits for music performances as an effort to control security and order. To grant permits and supervise public crowd activities and other community activities, fostering the community to increase community participation, public legal awareness and obedience to the laws and regulations of the public. order and ensuring public safety The factors inhibiting the authority of the National Police in issuing permits for music performances as an effort to control security and order There are permits for music performances that have not extended or have not made Performance Recommendations, Time $p$ a sudden application for permission which should have been 7 (seven) days before the activity or event took place, When the environmental permit statement letter was not approved by the environment around the location of the event.

Keywords: police; authority; licensing; protection.

\section{Introduction}

In relation to the life of a state, the National Police is an instrument of the state that plays a role in maintaining public security and order, upholding the law, and providing protection, protection and services to the community in the context of maintaining domestic security. In the midst of an increasingly difficult situation like this, the Police are faced with many challenges, in addition to being able to be a good law enforcement officer, Polri must also be good at being a community partner in terms of services, especially for people who are looking for justice, this is in accordance with Pancasila and 1945 Constitution. ${ }^{1}$

According to Satjipto Raharjo, the police are state instruments whose task is to maintain security and public order, provide protection and provide protection to the

${ }^{1}$ https://pospolisi.wordpress.com/2012/11/03/tugas-dan-wewenang-polri/, Accessed 2 June 2017 at 20.00 Jurnal Hukum Khaira Ummah Vol. 12. No. 3 September 2017 : 507 - 516 
public. ${ }^{2}$ Furthermore, Satjipto Raharjo quoted this opinion stating that if the law aims to create order in society, including the war against crime. Finally, the police will determine in concrete terms what is called a law enforcement order. ${ }^{3}$

The function of the police in Article 2 of the Police Law is one of the functions of the state government in the field of maintaining public security and order, law enforcement, protection, protection and services to the community. The Indonesian police as a law enforcement tool are primarily tasked with maintaining domestic security, in carrying out their duties to uphold human rights.

Regulations regarding the duties and powers of the police are regulated in Act No. 2 of 2002 concerning the Indonesian National Police. According to Article 13 of Act No. 2 of 2002 there are several police duties, namely:

- Maintain public security and order;

- Enforce the law;

- Providing protection, protection, and services to the community.

All levels of the policing functions to serve the community in dealing with legal problems related to the police, including granting permission to crowds and supervising music performance activities.

Music is part of people's life. He is a work of art that gives values to a nation. Basically, the Indonesian nation is a nation rich in arts and culture. One of the identities of the Indonesian nation is dangdut music. Dangdut music is part of the development of the nation's cultural treasures. He is an Indonesian cultural asset that must be protected. Ironically, the Indonesian people are "ashamed" of their own culture. This is due to the changes experienced by the music in its performances especially some local dangdut singers who are considered to give a bad image to dangdut music.

The name dangdut itself comes from the sound of this instrument which reads "dang" and "dut". Dangdut developed from the roots of Malay music around 1940 which was then touched by elements of Indian and Arabic music. In its development, dangdut music is open to receiving influences from other types of music, such as keroncong, rock, pop, house music, rap, even $\mathrm{r}$ and $\mathrm{b}$. The development of dangdut music in Indonesia began around 1950-1960, with the term Malay deli music that was endemic in Jakarta, then influenced by Indian music to become the forerunner of dangdut music. Entering the '70s era, Indonesia was hit by rock music from the West.

This encourages dangdut artists to continue to exist by following changes in people's tastes without eliminating the main elements of dangdut music, as was done by Rhoma Irama and Soneta Group. With extraordinary hard work, finally dangdut rock music was able to stand in line with rock music at home and abroad. The next edition entered the 90s era, Indonesia was again hit by music from abroad such as Reggae, Hip hop, and Mandarin. Even so, dangdut did not just disappear, dangdut showed its flexibility by merging into these new musical genres without losing the original elements of dangdut music. Entering the late 90's, dangdut music penetrated another genre of music, namely disco. In subsequent developments, around 2002,

\footnotetext{
${ }^{2}$ Raharjo, Satjipto. (2009). Penegakan Hukum Suatu Tinjauan Sosiologis Gentang Publisher Yogyakarta p. 111. Jurnal Daulat Hukum Volume 1 Issue 3 September 2018 ISSN: 2614560Xhttp://garuda.ristekbrin.go.id/documents/detail/1755554

IIbid. p. 117
} 
Indonesia was shocked by the appearance of Inul Daratista by rocking his drill. In each song, the music is arranged in such a way with variations of drums with beats that tend to be fast. This development gave birth to dangdut koplo, which every listener wanted to sway crazy. The development of dangdut towards koplo was influenced by foreign (western) cultures, such as the growing technology of musical instruments, as well as the development of fashion clothes. The future generations of dangdut feel out of date if they don't keep up with the current trends. But on the other hand, they also want to continue to exist in the dangdut world, so that dangdut performers try to collaborate their dangdut performances with the times.

Among the actions carried out by the group of dangdut koplo artists were in the Islamic and Eastern customary areas that maintained high values of politeness and upheld the prevailing norms and ethics. The bad influence that arises from the indecent appearance of the singer makes men err, especially when coupled with fantastic music. This pleasure becomes very delicious when they add liquor as a complement to the show.

Under the influence of drinking, it is difficult for them to control their thoughts so that doing things that are outside the limits becomes normal and can lead to social conflict. As in the conflict of dangdut music performances in the village of Jatisari Rt. 02 Rw. 03 Dist. Jakenan, Pati Regency, which was in the dangdut music stage, sparked a brawl between the audience. The causes of the brawl were different, including when one of the dangdut audiences, due to the enjoyment of enjoying the music and the shaking of the singer, made them sway and accidentally touched each other with different groups or other communities. Actually, the factor of accidentally touching each other is those who drink alcohol so that they get drunk. When they are drunk, they do not feel that the act of fighting is very dishonorable, it can disturb public security and order. Even though the show has received permission from the Police. Before issuing a permit, the Police had provided procedures and conditions for applying for a permit, one of which was to maintain the conduciveness of the show, but in fact, dangdut music often caused problems, social friction, fights and commotion.

Meanwhile, government uses the permit as a juridical means to control the behavior of the residents. By giving permission, the ruler allows the person requesting him to perform certain actions which are actually prohibited. ${ }^{4}$ Loyalp Local governments have different types of services according to the characteristics faced by each region. Service institutions also vary, both the provider and the form of the service provider agency. There are services that are still being carried out by offices or technical offices but there are also services that already have their own service institutions. ${ }^{5}$

Based on the description of the above problems, the author identifies legal problems, namely; What is the procedure for regulating the issuance of music stage permits in Pati Regency, How is the authority of the Police in issuing musical stage permits as an effort to control security and order in Jakenan district, Pati Regency,

\footnotetext{
${ }^{4}$ N.M. Spelt \& J.B.J.M. ten Berge (1993). Pengantar Hukum Perizinan. edited by Philipus M. Hadjon, Surabaya: Yuridika.p. 2

${ }^{5}$ Hendriyansyah. (2011). Kualitas Pelayanan Publik Konsep, Dimensi \& Implementasi, Gava Media, Yogyakarta. p. 74
} 
What are the factors inhibiting Polri's authority in issuing musical stage permits as an effort to control security and order in Jakenan District, Pati Regency and what is the solution.

\section{Research Methods}

This study uses an empirical juridical approach. According to Dyah Ochtorina and A'an Efendi, empirical juridical research includes research on legal identification (unwritten law) and research on legal effectiveness. ${ }^{6}$ Apart from explaining the legality of legal principles and legal aspects relating to the authority of the National Police in issuing permits for music performances as an effort to control security and order.

\section{Results and Discussion}

\subsection{Procedure for Issuance of Music Performance Permits in Pati Regency}

In addition to complying with procedures, the application for a permit must also fulfill certain conditions, depending on the type of permit, the purpose of the permit and the agency granting the permit that has been unilaterally determined by the Government. Even so, the Government may not determine the procedures and requirements according to its own will, but must operate in accordance with the existing regulations which have become the basis for such licensing. Regulation as a reference for issuing permits;

- Act No. 2 of 2002 concerning the Indonesian National Police.

- Show Chief of Police Field No. Pol. : Juklap / 02 / XII / 1995 dated 29 December 1995 concerning Licensing and Notification of Community Activities. ${ }^{7}$

- Web Criminal Law (KUHP) Article 510 concerning Public Crowds.

- Government Regulation Number 60 of 2017 concerning Licensing Procedures and Supervision of Public Crowd Activities, Other Community Activities, and Notification of Political Activities. In this Government Regulation.

\subsection{The authority of the National Police in issuing musical stage permits}

The authority of the National Police in issuing musical stage permits as an effort to control security and order in Jakenan District, Pati Regency. The authority that is owned is regulated in Article 15 paragraph (2), and secondly: the authority to investigate or investigate criminal proceedings, is regulated in Article 16 paragraph (1) of Act No. 2 of 2002 concerning the Indonesian National Police:

- Give permission and supervise public crowd activities and other community activities;

- Carry out registration and identification of motor vehicles;

- Providing a motorized vehicle driving license;

${ }^{6}$ Susanti, Dyah Ochtorina \& A'an Efendi. (2014). Penelitian Hukum (Legal Research). Jakarta: Sinar Grafika. p.18

${ }^{7}$ Juklap/02/XII/1995 on December 29, 1995 on Licensing \& Notification of Community Activities 8https://peraturan.bpk.go.id/Home/Details/64779 
- Receiving notifications about political activities;

- Give permission and carry out control over firearms, explosives and sharp weapons;

- Provide operational licenses and supervise business entities in the field of security services;

- Provide instructions, educate and train special police officers and independent security officers in the technical field of policing;

- Cooperating with the police of other countries in investigating and combating international crimes;

- To carry out police functional supervision of foreigners who are in the territory of Indonesia with related agencies;

- Representing the government of the Republic of Indonesia in an international police organization;

- Carry out other powers within the scope of police duties. ${ }^{9}$

\subsection{Factors inhibiting the authority of the National Police in issuing permits for musical performances}

Factors inhibiting the authority of the National Police in issuing permits for musical performances as an effort to control security and order in Jakenan District, Pati Regency and what are the solutions? In terms of issuing a music permit in Jakenan district, Pati Regency, there are several factors that have become obstacles to the issuance of the crowd permit. Based on the results of the author's interview with AIPDA SLAMET RAGIL, the Department of Intelligence and Security at the Police, these factors include: 10

- There is a music stage permit that has not extended or not made a Performance Recommendation.

- The time for a sudden permit application which should be 7 (seven) days before the activity or event takes place.

- When the environmental permit statement letter is not approved by the environment around the location of the event.

Efforts to overcome

- Coordinating with the Music Performance Organizing Committee to coordinate with music players and extend permits for music performances and those who have not made stage recommendations.

- Speed up completion of Administration files.

- Provide direction to the community through an approach and ensure the event will run smoothly, safely and orderly.

\section{Conclusion}

In addition to complying with procedures, the application for a permit must also fulfill certain conditions, depending on the type of permit, the purpose of the

\footnotetext{
${ }^{9}$ Act No. 2 of 2002, article 15 paragraph 2

${ }^{10}$ Interview with AIPDA Slamet Ragil, Head of Intelligence and Security, Police of Jakenan on September 26, 2020
} 
permit and the agency granting the permit that has been unilaterally determined by the Government. After the requirements are complete, a Music Performance Permit is issued by the Head of the Sector Police which is then submitted to the permit applicant and the local village. In terms of issuing permits, there are several factors that become obstacles to the issuance of these crowd permits. The existence of a music stage permit that has not extended or has not made a Performance Recommendation. The time for a sudden permit application should be 7 (seven) days before the activity or event takes place. When the environmental permit statement letter is not approved by the environment around the location of the event. Efforts to overcome it: Coordinating with the Music Performance Organizing Committee to coordinate with music players and extend music stage permits and those who have not made stage recommendations, Speed up the completion of administrative files. Provide direction to the community through an approach and ensure that the event will run smoothly, safely and orderly.

\section{References}

Journal:

[1] Raharjo, Satjipto. (2009). Penegakan Hukum Suatu Tinjauan Sosiologis Gentang Publisher Yogyakarta

[2] Jurnal Daulat Hukum Volume 1 Issue 3 September 2018 ISSN: 2614-560X http://garuda.ristekbrin.go.id/documents/detail/1755554

Books:

[1] Hendriyansyah. (2011). Kualitas Pelayanan Publik Konsep, Dimensi \& Implementasi, Gava Media, Yogyakarta

[2] N.M. Spelt \& J.B.J.M. ten Berge (1993). Pengantar Hukum Perizinan. edited by Philipus M. Hadjon, Surabaya: Yuridika

[3] Susanti, Dyah Ochtorina \& A'an Efendi. (2014). Penelitian Hukum (Legal Research). Jakarta: Sinar Grafika

Regulation:

[1] Act No. 2 of 2002, article 15 paragraph 2

[2] Juklap/02/XII/1995 on December 29, 1995 on Licensing \& Notification of Community Activities

Internet:

[1] https://peraturan.bpk.go.id/Home/Details/64779

[2] https://pospolisi.wordpress.com/2012/11/03/tugas-dan-wewenang-polri/, Accessed 2 June 2017 at 20.00 Jurnal Hukum Khaira Ummah Vol 12. No. 3 September 2017

Interview:

[1] Interview with AIPDA Slamet Ragil, Head of Intelligence and Security, Police of Jakenan on September 26, 2020 